\title{
Onychomadesis as a preemptive sign of pemphigus vulgaris exacerbation
}

\author{
Spełzanie płytek paznokciowych jako objaw wyprzedzający zaostrzenie pęcherzycy \\ zwykłej
}

\author{
Andrzej K. Jaworek', Agnieszka Oszywa², Anna Wojas-Pelc' \\ 'Department of Dermatology, Jagiellonian University Medical College, Krakow, Poland \\ ${ }^{2}$ Clinical Department of Dermatology, University Hospital, Krakow, Poland \\ 'Katedra i Klinika Dermatologii Collegium Medicum Uniwersytetu Jagiellońskiego w Krakowie, Polska \\ 2Oddział Kliniczny Dermatologii Szpitala Uniwersyteckiego w Krakowie, Polska
}

A 56-year-old male, physical worker, with pemphigus vulgaris (PV) lasting for 6 months (diagnosed based on guidelines of the Polish Dermatological Society: linear IgG and complement deposits in intercellular spaces of the epidermis found in the biopsy specimen collected from the vesicular area (direct immunofluorescence), pemphigus type antibodies with titre of $1: 1000$ on monkey oesophagus (indirect immunofluorescence), presence of anti-desmoglein 3 antibodies (result: +++ ) and of anti-desmoglein 1 antibodies (+++) (ELISA method) was admitted to the Teaching Department of Dermatology with another episode of exacerbation of the disease. Before the admission the patient was treated with prednisolone $(60 \mathrm{mg}$, b.w. $60 \mathrm{~kg})$ and azathioprin $(150 \mathrm{mg})$, with achievement of the phase of consolidation of dermatological lesions. Approximately 2 months before the admission the patient observed onychomadesis of fingernails. Clinical examination demonstrated presence of numerous, locally extensive erosions, dried blisters partially covered with scab on the skin on the trunk, face, upper extremities and scalp (figs. 1-3). There were painful erosions present on oral and nasal mucosa. Additionally, onychomadesis was observed on both hands, on fingers I-IV (figs. 4 and 5). Toenails were not affected. The patient negated any additional ailments, and used no other systemic medication. Changes within fingernails preceded by approximately 7 weeks the appearance of new blisters on the oral mucosa and skin.

Pemphigus vulgaris is a rare acantholytic bullous disease of mucosa and skin, caused by pathogenic auto-antibodies against various desmosomal adhesion molecules [1]. Nail-associated lesions are rarely reported in PV. However, in the 2018 report
Mężczyzna 56-letni, pracownik fizyczny, z 6-miesięczym przebiegiem pęcherzycy zwykłej (pemphigus vulgaris - PV) - rozpoznanej na podstawie wytycznych Polskiego Towarzystwa Dermatologicznego: linijne złogi IgG oraz komplementu w przestrzeniach międzykomórkowych naskórka w wycinku z otoczenia pęcherza (immunofluorescencja bezpośrednia), przeciwciała typu pemphigus w mianie $1: 1000$ na przełyku małpy (immunofluorescencja pośrednia), obecność przeciwciał przeciw desmogleinie 3 (wynik: +++ ) oraz desmogleinie $1(+++)$ (metoda ELISA) - został przyjęty do Kliniki Dermatologii z kolejnym zaostrzeniem choroby. Przed przyjęciem pacjent był leczony prednizolonem $(60 \mathrm{mg}$, masa ciała $60 \mathrm{~kg}$ ) oraz azatiopryną (150 mg) i uzyskał fazę konsolidacji zmian skórnych. Około 2 miesięcy przed przyjęciem chory zauważył spełzanie płytek paznokciowych w obrębie paznokci rąk. W trakcie badania klinicznego stwierdzono liczne, niekiedy duże nadżerki, przyschnięte pęcherze pokryte częściowo strupami na skórze tułowia, twarzy, kończyn górnych oraz głowy owłosionej (ryc. 1-3). Na błonach śluzowych jamy ustnej i nosa obecne były rozsiane, bolesne nadżerki. Dodatkowo w obrębie narządu paznokciowego obu rąk obserwowano spełzanie płytek paznokciowych palców I-IV (ryc. 4 i 5). Paznokcie stóp nie były zmienione chorobowo. U pacjenta nie występowały dodatkowe dolegliwości, nie stosował ogólnie innych leków. Zmiany paznokciowe poprzedziły o ok. 7 tygodni pojawienie się nowych pęcherzy na błonie śluzowej jamy ustnej oraz na skórze.

Pęcherzyca zwykła jest rzadką, akantolityczną chorobą pęcherzową błon śluzowych i skóry wywołaną obecnością patogennych autoprzeciwciał skierowanych przeciwko różnym cząsteczkom adhezyjnym desmosomów [1]. Zmiany paznokciowe w przebiegu PV są opisywane rzadko, chociaż w pracy autorów indyjskich 


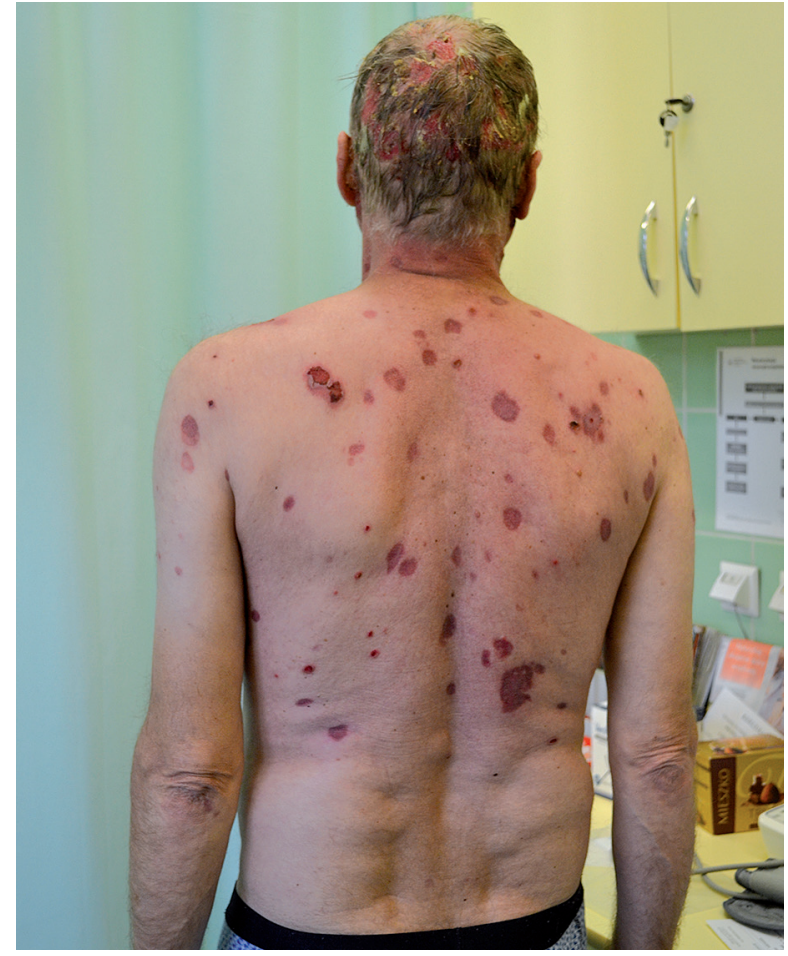

Figure I. Numerous, diffuse erosions, discolorations and residual bullous lesions located in the skin of the back. Diffused erosions and stratified crusts in the scalp skin

Rycina I. Liczne, rozsiane nadżerki i przebarwienia oraz resztkowe zmiany pęcherzowe zlokalizowane na plecach. Rozsiane nadżerki oraz uwarstwione strupy na skórze głowy owłosionej

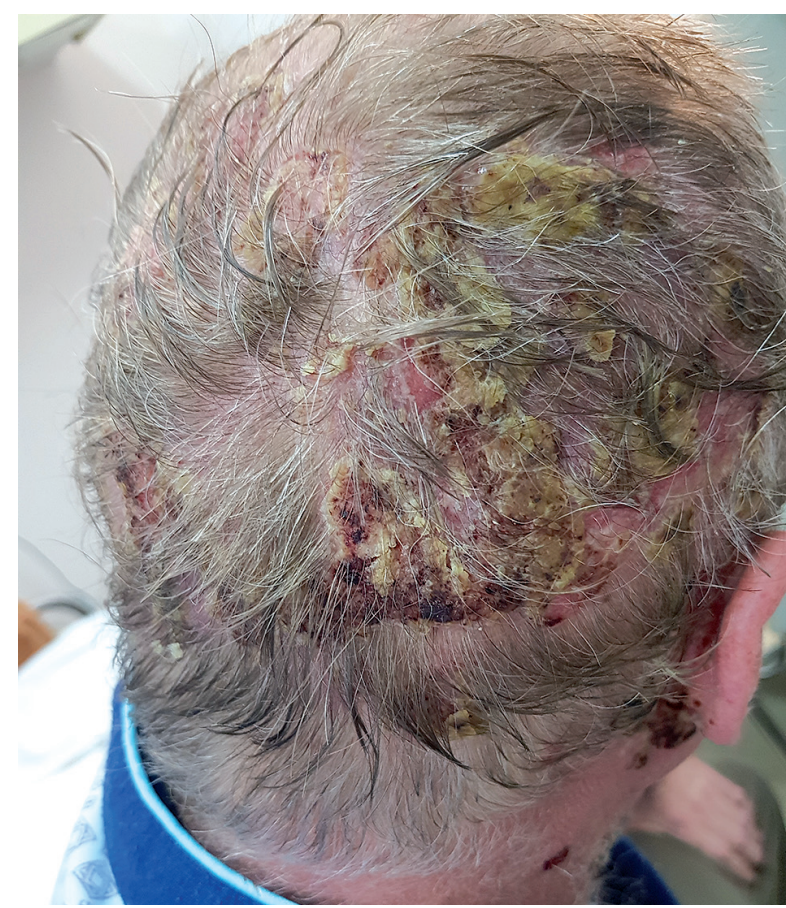

Figure 3. Extensive erosions, partially covered in scale crusts involving a scalp

Rycina 3. Nasilone, zlewne nadżerki, miejscami pokryte łuskami i strupem w obrębie głowy owłosionej

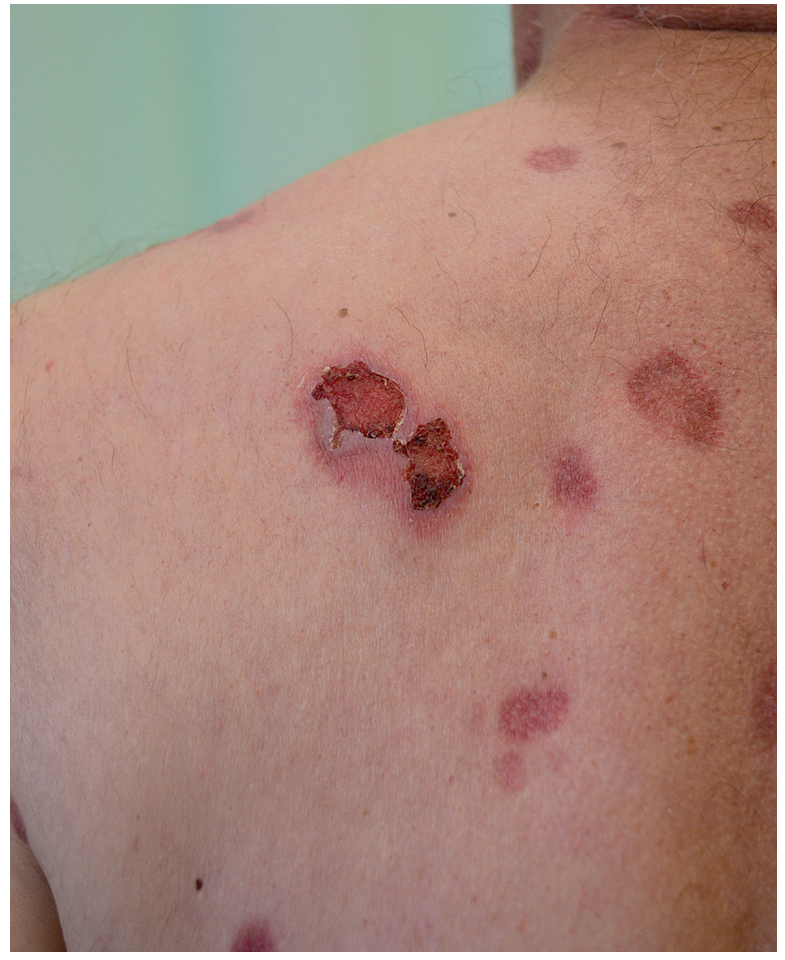

Figure 2. Erosion with residual blister on the margin

Rycina 2. Nadżerka z elementami pęcherza na obwodzie w obrębie lewego ramienia

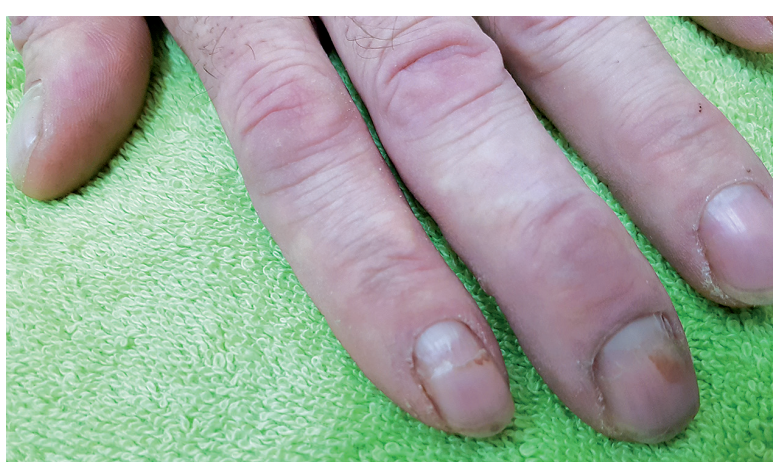

Figure 4. Nail plate exfoliation (left hand)

Rycina 4. Złuszczanie płytek paznokciowych (lewa ręka)

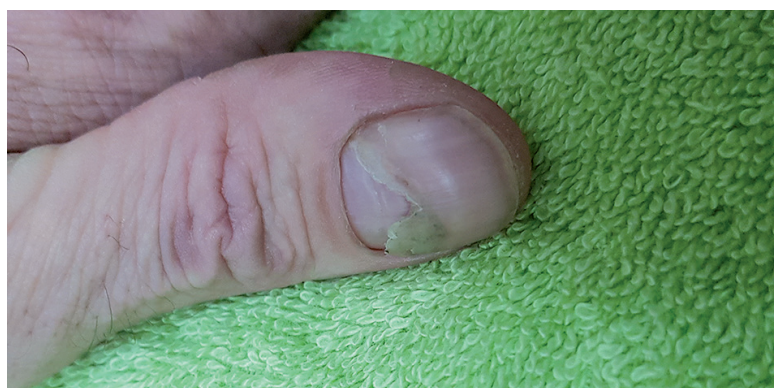

Figure 5. Nail plate exfoliation (left thumb)

Rycina 5. Złuszczanie płytek paznokciowych (lewy kciuk) 
of Indian authors they were observed in $70 \%$ of analysed patients [2]. The most commonly observed lesions occurring in course of PV within the nail system are: paronychia, onychorrhexis, distal onycholysis, onychomadesis, transverse grooves on the nail plate (Beau lines) or dot-like defects of nail plates (pitting), pterygium (a skin fold extending from the proximal wall of the nail and dividing nail plate into two parts), excessive subonychial keratosis, discolorations of nail plates, subonychial petechiae, and even onychodystrophy [2,3]. Fingernails are usually affected. Part of lesions observed in patients (particularly onychomycosis) result from drug-induced immunosuppression [2]. Onychomadesis is a process associated with temporal, total arrest of growth of a nail plate within the nail matrix, resulting in formation of a transverse fissure dividing the nail plate into two separate parts, with a gradual separation of the distal part by the growing proximal one. That complication was described by several authors in papers focused on the analysis of bullous diseases [2, 4-6]. The paper by Pietkiewicz et al. is particularly interesting [7]. The authors analysed a group of Polish PV patients (67 individuals). Nine of them (13.4\%) presented lesions of nails (including 4 with onychomadesis).

A precise mechanism of pathogenesis of lesions developing in course of PV within the nail system is not fully understood. Despite that tissues of the nail system demonstrate expression of desmosomal cadherins, their sequestration within the proximal nail matrix (PNM) seems to be responsible for a kind of "immune preference" of that body part. Expression of desmogleins 1 and 3 within the nail system is reduced (reduction or absence of the granulous layer of the epidermis). That is a reason for which PV lesions develop only in presence of high levels of pathogenic auto-antibodies in blood [7,8].

The presented case indicates the necessity of overall analysis of dermatological symptoms of all skin appendages in PV cases (analysis that is frequently neglected). The analysis of potential changes occurring within the nail system is particularly important because of potential infections in that area, and because - as pointed out by some researchers - they constitute a significant factor predisposing for severe course of the underlying condition [7].

\section{CONFLICT OF INTEREST}

The authors declare no conflict of interest. z 2018 roku występowały u ponad 70\% badanych pacjentów [2]. Do najczęstszych zmian w obrębie aparatu paznokciowego w przebiegu PV należą: zapalenie wałów paznokciowych (paronychia), podłużna łamliwość paznokci (onychorrhexis), onycholiza dystalna, spełzanie (złuszczanie) płytek paznokciowych (onychomadeza), poprzeczne wgłębienia w obrębie płytki paznokciowej (linie Beau) lub punkcikowate ubytki w obrębie płytki paznokciowej (pitting), skrzydlik (fałd skórny narastający od proksymalnego wału paznokciowego, który przedziela płytkę paznokciową na dwie części), nadmierne rogowacenie podpaznokciowe, zmiany zabarwienia płytek paznokciowych, wybroczyny podpaznokciowe, a także onychodystrofia [2, 3]. Zazwyczaj zajęte są paznokcie rąk. Część zmian paznokciowych obserwowanych u pacjentów z pęcherzycą (zwłaszcza grzybice paznokci) wynika z leczenia immunosupresyjnego [2]. Onychomadeza to proces związany z czasowym, całkowitym zatrzymaniem produkcji płytki paznokciowej w obrębie macierzy paznokcia, w wyniku którego dochodzi do powstania poprzecznej szczeliny dzielącej płytkę paznokciową na dwie oddzielne części, ze stopniowym oddzieleniem części dystalnej przez rosnącą część proksymalną. Powikłanie to opisało kilka grup badaczy w pracach analizujących zmiany w obrębie paznokcia w przebiegu chorób pęcherzowych [2, 4-6]. Na szczególną uwagę zasługuje praca Pietkiewicza i wsp. [7]. Autorzy przeprowadzili analizę grupy polskich chorych na PV (67 osób). U 9 (13,4\%) z nich występowały zmiany paznokciowe (w tym u 4 onychomadeza).

Dokładna patogeneza zmian w obrębie aparatu paznokciowego w przebiegu PV nie jest poznana. Pomimo że tkanki aparatu paznokciowego wykazują ekspresję kadheryn desmosomalnych, to wydaje się, że ich sekwestracja w obrębie części proksymalnej macierzy paznokcia (proximal nail matrix - PNM) może odpowiadać za pewne „uprzywilejowanie immunologiczne" tej części ciała. Ekspresja desmoglein 1 oraz $3 \mathrm{w}$ obrębie aparatu paznokciowego jest zmniejszona (redukcja lub brak warstwy ziarnistej naskórka), co powoduje, że zmiany w przebiegu PV występują tylko w przypadku wysokich stężeń patogennych przeciwciał we krwi $[7,8]$.

Przedstawiony przypadek wskazuje, że standardem postępowania klinicznego u pacjentów z PV powinna być w każdym przypadku (często pomijana) całościowa analiza objawów dermatologicznych wszystkich przydatków skóry. Analiza potencjalnych zmian w obrębie aparatu paznokciowego jest szczególnie istotna ze względu na możliwość infekcji w tym obszarze oraz - co podkreśla część badaczy - z powodu szczególnie ciężkiego przebiegu choroby podstawowej u pacjentów ze zmianami w tej lokalizacji [7].

\section{KONFLIKT INTERESÓW}

Autorzy nie zgłaszają konfliktu interesów. 


\section{References}

\section{Piśmiennictwo}

1. Kowalewski C., Dmochowski M., Placek W., Waszczykowska E., Nowicki R., Flisiak I., et al.: Diagnosis and therapy of pemphigus - consensus of Polish Dermatological Society. Dermatol Rev 2014, 101, 147-155.

2. Gopal V., Shenoy M.M., Bejai V., Nargis T.: Nail changes in autoimmune blistering disorders: a case-control study. Indian J Dermatol Venereol Leprol 2018, 84, 375-379.

3. Carducci M., Calcaterra R., Franeo G., Mussi A., Bonifati C., Morrone A.: Nail involvement in pemphigus vulgaris. Acta Derm Venereol 2008, 88, 58-93.

4. Habibi M., Mortazavi H., Shadianloo S., Balighi K., Ghodsi S.Z., Daneshpazhooh M., et al.: Nail changes in pemphigus vulgaris. Int J Dermatol 2008, 47, 1141-1144.

5. Schlesinger M., Katz M., Ingber A.: Nail involvement in pemphigus vulgaris. Br J Dermatol 2002, 146, 836-839.

6. Engineer L., Norton L.A., Ahmed A.R.: Nail involvement in pemphigus vulgaris. J Am Acad Dermatol 2000, 43, 529-535.

7. Pietkiewicz P., Bowszyc-Dmochowska M., Gornowicz-Porowska J., Dmochowski M.: Involvement of nail apparatus in pemphigus vulgaris in ethnic poles is infrequent. Front Med 2018, 5, 227.

8. Laffitte E., Panizzon R.G., Borradori L.: Orodigital pemphigus vulgaris: a pathogenic role of anti-desmoglein-3 autoantibodies in pemphigus paronychia? Dermatology 2008, 217, 337-339.

Received: 27.02 .2019

Accepted: 28.02 .2019

Otrzymano: 27.02.2019 r.

Zaakceptowano: $28.02 .2019 \mathrm{r}$. 